Volume 2 No. 2, Desember 2017

P ISSN 2442-594X | E ISSN 2579-5708

http://journal.iainlangsa.ac.id/index.php/tibyan

\title{
KEMAKSUMAN NABI: KAJIAN TERHADAP AYAT-AYAT 'ITÂB TERHADAP NABI MUHAMMAD SAW
}

\author{
Prosperity Of Prophet: Study On Verses 'Itâb To The Prophet Of Muhammad Saw
}

\author{
Sriwahyuni \\ Institut Agama Islam Negeri Malikussaleh Lhokseumawe \\ faisalyahya82@gmail.com
}

\begin{abstract}
Abstrak
This article aims to understand what the concept of the infallibility of prophets and messengers by seeing some interpretations of some verses contained in the Qoran are considered as 'itâb (admonition/warning) for one of the prophets, he is the prophet Muhammad pbu. The data of this study was obtained through primary literature, it is an interpretation literature (kitab tafsir) of classic interpreter (mufassir) and some modern interpreters. This study was discussed in the descriptive-comparative analysis by using the infallibility ('ismah )theory . Initially, the writer described admonition's verses that will be studied by comparing it with two other interpretations, and then analyzed it. Thus it was found that interpreters differed in recognizing the exictence of admonition's verses to the prophet Muhammad pbu in the Qoran. Finally, the study has analyzed and was found that the admonitions were not for a mistake or a sin that will eliminate the infallibility attribute that had attached to him, but it was as manifestations of the compassion of Allah to the Prophet in order to not too forces his self in preaching, because however he had do all the commands of Allah to convey all of his message or revelation.
\end{abstract}

Keywords: Prosperity, 'ísmah, 'itâb, tafsir

\begin{abstract}
Abstrak
Artikel ini bertujuan untuk memahami apa konsep kemaksuman nabi dan rasul dengan melihat penafsiran terhadap beberapa ayat yang terdapat di dalam alQur'an yang dipersepsi sebagai 'itâb (celaan) terhadap Nabi Muhammad SAW. Data penelitian ini diperoleh melalui literatur primer yaitu tafsir karya mufassir klasik dan beberapa tafsir modern. Kajian ini dibahas secara deskriptif-analisis komparatif dengan mengunakan teori 'ishmah. Awalnya, penulis mendeskripsikan ayat-ayat celaan tersebut beserta penafsirannya dengan membandingkannya dengan dua tafsir lain(penafsiran siapa?), baru kemudian menganalisanya. Mufassir berbeda pendapat mengenai keberadaan ayat-ayat
\end{abstract}


celaan bagi Nabi Muhammad SAW dan dapat disimpulkan bahwa celaan tersebut bukan karena suatu kesalahan atau dosa yang dapat menghilangkan sifat maksum yang melekat pada dirinya, melainkan karena wujud kasih sayang Allah SWT agar Nabi SAW tidak terlalu memberatkan diri atau memaksakan diri dalam berdakwah, karena bagaimana pun ia telah melakukan semua perintah Allah SWT yaitu menyampaikan semua risalah-Nya.

Kata Kunci: Maksum, 'ịsmah, 'itâb, tafsir

\section{Pendahuluan}

Para nabi dan rasul merupakan sosok yang sangat penting dalam perkembangan Islam. Salah satu di antara mereka adalah Nabi Muhammad SAW. Ia adalah contoh insân kâmil (manusia sempurna), yang setiap perkataan dan perbuatannya selalu berusaha untuk diikuti dan menjadi uswah ${ }^{1}$ dalam kehidupan. Ia juga Nabi terakhir ${ }^{2}$ yang membawa risalah untuk seluruh ummat yang kedatangannya sebagai pembawa berita gembira (basyîr) dan peringatan (nadzîr). Selaku penerima wahyu (al-Qur'an), maka ia pun menjadi mufassir pertama yang menjelaskan maksud dari ayat-ayat alQur'an tersebut melalui Sunnah atau $\underline{\text { Haditsnya. }}{ }^{3}$

Banyak literatur yang membahas tentang kemuliaan akhlak Nabi Muhammad SAW yang lahir akibat kekaguman terhadapnya, baik dari segi fisik maupun non-fisik. ${ }^{4}$ Tidak hanya dari muslim, ada juga non-muslim yang kagum dengan keluhuran budinya. Sebagai contoh, Michael Hart yang menempatkannya di urutan pertama di antara deretan para tokoh lain yang ditulisnya dalam buku "Seratus Tokoh Dunia yang Paling Berpengaruh dalam Sejarah" ${ }^{5}$ Hal ini bukan berarti menafikan beberapa orang yang justru membencinya dengan melontarkan hal-hal negatif dan memfitnahnya, bahkan ini sudah terjadi semenjak Nabi SAW masih hidup. Misalnya para orientalis dan beberapa pemikir Muslim yang mengatakan bahwa Muhammad telah melakukan intervensi dalam kegiatan jam'u al-Qur'ân, dan lainnya

Kelebihan yang Allah SWTberikan kepada Nabi Muhammad SAW ternyata mempunyai alasan dan tujuan yang sangat besar. Al-Qur'an yang diwahyukan kepadanya merupakan anugerah sekaligus amanah yang amat besar dan berat untuk ia terima. Al-Qur'an merupakan mukjizat terbesar yang diberikan kepadanya di samping

\footnotetext{
${ }^{1}$ Uswah adalah suri tauladan yang baik

${ }^{2}$ Sebagaimana firman Allah SWT dalam surat al-Ahzâb/33: 40. Kata-kata Khâtam al-nabiyyîn ditafsirkan oleh mayoritas ulama sebagai nabi penutup atau terakhir

${ }^{3}$ Mayoritas ulama Hadîts mendefinisikan Sunnah atau Hadîts sebagai segala sesuatu yang diambil dari Rasul SAW baik berupa sabda, perbuatan, taqrîr (ketetapan), sebelum maupun sesudah diangkat menjadi rasul, baik membawa konsekuensihukum syara' maupun tidak. Ini merupakan definisi yang paling luas cakupannya di antara definisi-definisi lainnya

${ }^{4}$ Seperti Ibnu Jauzi, al-Wafa; Kesempurnaan Pribadi Nabi Muhammad SAW, ed. 2. Penerjemah Mahfud Hidayat dan Abdul Muiz (Jakarta: Pustaka al-Kautsar, 2008). Buku ini panjang lebar menguraikan keutamaan Nabi Muhammad dilihat dari berbagai aspek

${ }^{5}$ Di antara literatur lainnya adalah On Heroes, Hero, Worship and The Heroes in History karya Thomas Carlyle dan The Story of Civilization in The World karya Will Durant
} 
mukjizat-mukjizat lainnya. Di dalamnya tersurat undang-undang kehidupan yang mencakup segala aspek kehidupan. Al-Qur'an diturunkan dalam bahasa Arab, yang mana tidak semua orang dapat memahaminya dengan baik, termasuk orang Arab sendiri; di sinilah Nabi SAW berperan. Allah SWT memberikan kepadanya legitimasi untuk menafsirkan ayat-ayat al-Qur'ân yang tentunya di bawah bimbingan dan petunjuk langsung dari-Nya, yang - disebut sebagai hadîts atau sunnah.

Menjadi seorang nabi berarti menjadi sebagai seorang mubalig. Salah satu faktor keberhasilan seorang penyeru (mubalig/dai) adalahsikap dan tingkah laku sang dai. Menjadi seorang nabi dan rasul seperti Muhammad SAW memang dituntut untuk memiliki akhlak yang mulia dan terbebas dari kesalahan (maksum). Hal ini akan berpengaruh pada jalannya misi kenabian yang ia emban. Tidak mungkin orang yang diseru mau mengikuti penyeru yang melakukan kebalikan dari apa yang ia serukan, dan tidak pantas seorang yang mengajak kepada kebaikan melakukan perbuatan dosa dan kemaksiatan. Maka kemuliaan akhlak menjadi salah satu faktor yang menentukan berhasil atau tidaknya dakwah seseorang.

Allah SWT banyak menyebut ayat-ayat yang memuji kemulian akhlak Nabi Muhammad SAW dalam al-Qur'an. ${ }^{6}$ Di samping itu, Allah SWT juga mengabadikan beberapa ayat yang seolah-olah tidak sejalan dengan pujian-pujian-Nya. Ayat ini adalah ayat yang Allah SWT turunkan untuk menegur beberapa sikap Nabi SAW, yang disebut dengan ayat 'itâb (celaan).

Dalam mengrespon hal ini - melahirkan banyak perbedaan pendapat dari berbagai kalangan, terutama kalangan ulama kalam (teolog Islam) dan ulama tafsir. Perbedaan ini bolehjadi disebabkan oleh perbedaan intelektualitas dan mazhab terutama mazhab Ilmu Kalam-yang dipegang, serta sikap dalam memposisikan alQur'an dan Nabi Muhammad SAW. Di satu sisi, dalam kajian teologi Islam, Allah SWT mengutus nabi-Nya dengan menyertakan sifat maksum (terpelihara dari salah dan dosa) baginya di samping sifat siddîq, amânah, tablîgh dan fathânah. Sifat maksum tersebut menjadi penentu keempat sifat lainnya. Karena kemaksumannya, maka Nabi bisa menjadi seorang yang mampu berlaku benar dan jujur, dapat dipercaya, mampu menyampaikan - risalah Allah SWT tanpa melakukan revisi, menambah atau menguranginya serta seorang yang cerdas. Di sisi lain, di dalam al-Qur'an ternyata Allah SWT juga menyebutkan ayat-ayat yang menegur beberapa sikap Nabi SAW. Dua sisi yang seolah berbeda ini kemudian melahirkan pertanyaan, jika Nabi SAW telah dilengkapi dengan sifat maksum, kenapa Allah SWT menegur sikapnya? Apakah ia bersalah? atau jika Allah SWT menegur Nabi-Nya, di manakah letak kemaksuman yang telah Ia anugerahkan kepadanya? pertanyaan-pertanyaan ini menjadi latar belakang penulisan artikel ini dengan melihat bagaimana para mufassir menafsirkan ayat-ayat yang menegur Nabi SAW dan kaitannya dengan konsep 'ișmah al-anbiyậ.

Data -artikel ini dikumpulkan melalui studi kepustakaan (library research) terhadap ayat-ayat 'itâb yang ditujukan kepada Nabi Muhammad SAW sebagai data

\footnotetext{
${ }^{6}$ Seperti di dalam surat al-Qalam ayat 4
} 
utama dan mengunakan beberapa kitab tafsir yang mewakili zaman dan pemikiran teologisnya. Kitab tafsir klasik yang digunakan adalah kitab Tafsir Jâmi' al-Bayân 'an Tạîl Âyi al-Qựan karya Imam al-Tabari, ${ }^{7}$ sedangkan tafsir modern digunakan Tafsir al-Mîzânkarya Al-Ṭabậtabâaî sebagai seorang mufassir Syi'ah dan juga Tafsir al-Misbah karya Quraish Shibab sebagai tafsir Sunni.

Kajian ini menggunakan metode pembahasan deskriptif-analisis-komparatif, yaitu dengan mendeskripsikan ayat-ayat yang mencela Nabi Muhammad SAW serta bagaimana sang mufassir berbicara tentang ayat-ayat tersebut. Selanjutnya penulis menganalisa penafsiran-penafsiran tersebut dengan berusaha untuk membandingkannya dengan penafsiran ulama lain agar pembahasannya lebih luas.

Kajian ini berangkat dari teori yang berkaitan dengan konsep kemaksuman nabi yang merupakan sebuah keniscayaan bagi seorang nabi di samping sifat-sifat lainnya. Muhammad 'Âlî al- $\underline{S} a ̂ b \underline{u} \hat{1}^{8}$ menyebutkan bahwa para nabi memiliki 6 sifat, termasuk di dalamnya maksum. Sifat-sifat tersebut adalah : siddîq (benar/ jujur), amânah (terpercaya), tablîgh (menyampaikan risalah), fathânah (cerdas),

al-salâmah min al-'uyub al-munaffirah (bebas dari cacat yang menjijikkan), dan 'ismah (terbebas dari dosa). Keempat sifat pertamadi atas menunjukkan bahwa para nabi dan rasul adalah maksum(terbebas) dari dosa.

\section{Pembahasan Hasil Penelitian}

\section{Pengertian ayat 'Itâb}

Secara bahasa, 'itâb berasal dari kata ( عتب- يعتب) 'ataba ya'tibu yang berarti menegur, mencela, dan memperingatkan. 'Itâb sendiri bermakna celaan, teguran atau peringatan, yang juga disebut dengan istilah 'atbun, jamaknya 'utbân. ${ }^{9}$ Al-'Itâb juga diartikan dengan suatu pembicaraan atau percakapan yang mencela.

Adapun secara istilah, 'itâb didefinisikan dengan beberapa makna, yaitu:

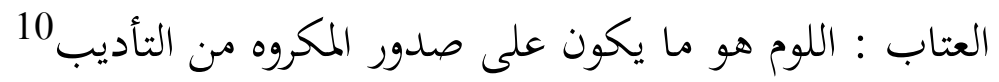

'Itâb adalah suatu kecaman atau celaan terhadap suatu hal yang dibenci yang merupakan bagian dari mendidik.

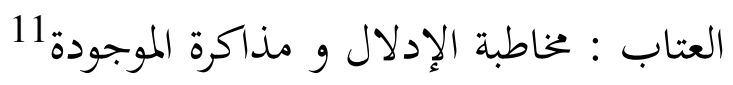

\footnotetext{
${ }^{7}$ Kitab tafsir ini juga termasuk ke dalam kitab tafsir yang paling utama dan paling lengkap pada masa itu, serta yang paling tua. Lihat M. Quraish Shihab, "Ibnu Jarîr al-Tabari; Guru Besar Para Ahli Tafsir," Ulumul Qur'an, (April-Juni 1989): h. 41. Mani’ Abd Halîm Mahmụ̂d, Metodologi Tafsir ; Kajian Komprehensif Metode Para Ahli Tafsîr. Penerjemah : Faisal Saleh dan Syahdianor (Jakarta : PT RajaGrafindo Persada, 2006), h. 67. Muhammad Husein al-Dzahabi, al-Tafsîr wa al-Mufassirûn, juz I, (Kairo: Maktabah Wahbah, t.t.), h. 215

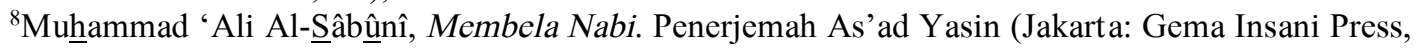
1412 H / 1992 M), h. 21-36

${ }^{9}$ Atabik Ali dan Ahmad Zuhdi Mahdhar, Kamus al- 'Asrî, (Yogjakarta: Multi Karya Grafika, 1998), h. 1269

10 Muhammad Amîn Al-Iḥsân Al-Burtakî, Qawâ‘id al-Fiqh, jil. 1, (Bibalsyâriz: Țab‘u al-Ṣadfi, 1986), h. 372

11 'Abdul Al-Raûf Al-Manâwî, al-Ta'ârif, jil.1, (Beirut: Dâr al-Fikr, 1410), h. 501
} 
'Itâb adalah sesuatu pembicaraan yang mengecam, mencela dan memperingati.

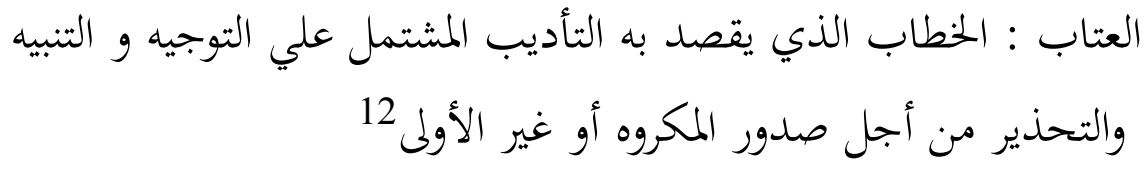

'Itâb adalah pembicaraan yang bertujuan untuk mendidik, termasuk juga mengarahkan, memperingatkan atau tahdzîr karena melakukan suatu hal yang makruh (dibenci) atau suatu hal yang tidak lebih baik atau utama. ${ }^{13}$

Berdasarkan beberapa definisi di atas terlihat bahwa 'itâb merupakan suatu ungkapan atau sikap satu pihak yang tidak setuju (ridha) dengan sikap pihak yang lain. Ketidakridhaan tersebut diwujudkan melalui teguran dalam rangka untuk memperbaiki sikap pihak yang ditegur. Selain sebagai usaha untuk memperbaiki, 'itâb ini juga bertujuan mendidik dan memberi peringatan agar orang yang ditegur melakukan hal yang lebih baik.

\section{Makna Ma'sûm}

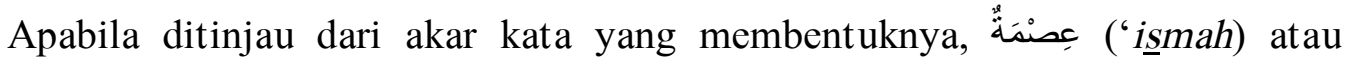

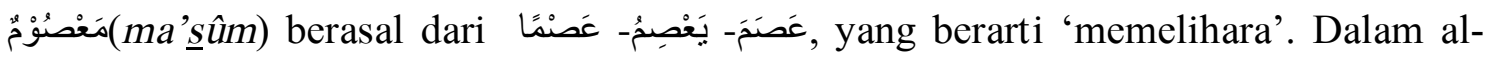
Qur'an, kata ma'sûm digunakan tiga belas kali dalam berbagai bentuk, namun semuanya mengandung satu pengertian, yaitu sَ menahan diri dan : mencegah. ${ }^{14}$ Apabila dikatakan عَصَمَ اللَّهُ فُلَناً , maka itu berarti Allah memelihara si fulan. عَصَمَ الثَىًَ berarti menegakkan, mencegah atau melarang sesuatu. Secara singkat, maka ma'ŝum berarti orang yang terpelihara, dan 'ismah adalah pemeliharaan atau perlindungan.

Menurut istilah, ma'sûm berarti suci dari berbuat dosa atau yang terpelihara dari berbuat dosa, kesalahan-kesalahan dan kekeliruan-kekeliruan. Dalam Ensiklopedi Aqidah Islam disebutkan bahwa 'ismah dalam konteks teologi berarti perlindungan Tuhan terhadap para nabi-Nya sehingga mereka bersifat ma'sûm, yaitu terhindar dan terlindung dari perbuatan dosa. ${ }^{15}$ Syeikh Ja'far al-Shubhani, dalam bukunya 'Ishmah: Keterpeliharaan Nabi dari Dosa menyebutkan bahwa kata 'ismah yang benar

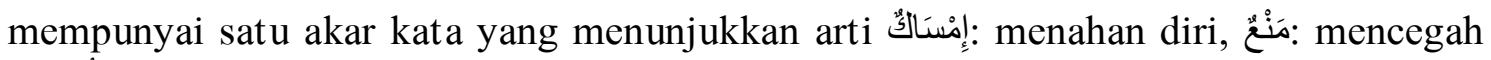

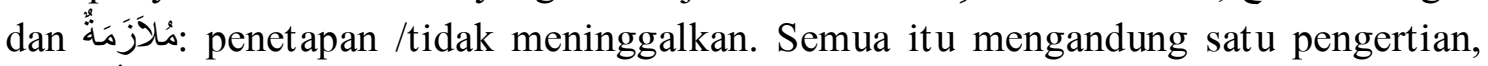
yaitu عِصَْة yang berarti pemeliharaan Allah SWT terhadap hamba-Nya dari keburukan yang akan menimpanya dan hamba itu berpegang teguh kepada Allah SWT dengan demikian ia tercegah dan terlindungi. ${ }^{16}$

\footnotetext{
${ }^{12}$ Amîn Muhammad Salâm Al-Munâsiyah, Nazrah fî Âyât al-'Itâb, dalam Majalah Jâmi 'ah Damsyîq li al-'Ulûm al-Iqtịsâdiyyah wa al-Qânûniyyah, edisi 23, 2007, h. 324

${ }^{13}$ Salâh'Abdu Al-Fattâh Al-Khâlidî, 'Itâb al-Rasûl fî al-Qựân: Tahlîl wa Taujîh, (Damsyîq: Dâr alQalam, 2002), h. 8 dan Muhammad 'Alî Al-Sâbûnî, Membela Nabi, h. 97

${ }^{14}$ Syeikh Ja'far Subhani, Ishmah: keterpeliharaan Nabi Dari Dosa. Penerjemah Syamsuri Rifa'i (ttp. Penerbit Yayasan As-Sajjad, 1405 H / 1991 M), h. 7

${ }^{15}$ Muslim Nasution, dkk., "Ishmah,” Syahrin Harahap dan Hasan Bakti Nasution, ed., Ensiklopedi Aqidah Islam, (Jakarta: Kencana, 2003), h. 178; Muhammad Ali Al-Shabuni, Membela Nabi, h. 39

${ }^{16}$ Subhani, Ishmah: keterpeliharaan Nabi, h. 7
} 
Apabila berpijak pada pengertian di atas, maka ketika dikatakan عَصَمْتُ فُلْانَاً, itu berarti saya memelihara si fulan, yakni saya menyediakan sesuatu untuknya, ia berpegang teguh dengan apa yang ia peroleh di tangannya, yaitu ia berlindung dan berpegang teguh dengannya. Kataَdalam surat Âli 'Imran ayat 103 berarti berpegang teguh dan memeliharanya dengan sungguh-sungguh dan segala kemampuan. Sedangkan kata فَاسنتَعْصَنَ dalam surat Yussuf ayat 32 mengandung makna mencegah dan menahan diri.

Apabila definisi-definisi di atas dibandingkan, maka secara umum maksudnya tidak jauh berbeda. Hanya saja dalam hakikatnya terjadi perbedaan antara golongan tertentu dalam menentukan siapakah yang dianggap ma'sûm (sasarannya) dan tidak. Dalam hal ini misalnya antara Sunni dan Syi'ah(kalimat ini belum sempurna).

Di kalangan Sunni, konsep ma'ŝum hanya berlaku bagi para nabi dan rasul saja. Sehingga yang dimaksudkan dengan 'ísmah menurut kelompok ini adalah pemeliharaan Allah SWT terhadap para nabi dan rasul-Nya dari perbuatan dosa dan maksiat, dari kemungkaran-kemungkaran dan perkara-perkara yang diharamkan. Sifat ma'ŝum ini merupakan sifat esensial yang melekat pada diri para nabi dan rasul yang membedakan mereka dengan manusia pada umumnya.

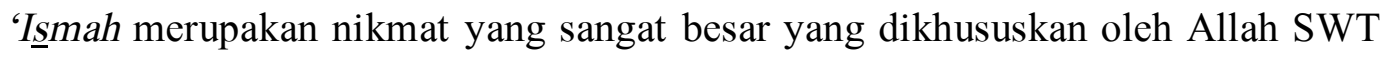
untuk para nabi saja, sehingga dengan demikian terselamatkanlah mereka dari segala macam dosa dan maksiat, baik besar maupun kecil, dan terselamatlah dari menyalahi perintah-perintah Allah SWT, tidak seperti orang lain. ${ }^{17}$ Dalam hal ini 'ismah bukanlah suatu hal yang bisa dicapai oleh setiap orang walaupun melalui usaha-usaha tertentu. Ia hanyalah anugerah dari Allah SWT. Hal ini tentu berbeda dengan apa yang diyakini oleh komunitas Syi'ah, yang mana mereka berpendapat bahwa ma'ŝum tidak hanya disandangkan kepada para nabi dan rasul, tetapi juga kepada para Imam Syi'ah.

Konsep 'ismah atau ma’ŝum merupakan suatu konsep yang hanya dibahas dalam Islam. Para teolog Yahudi tidak perlu membahas tema ini karena mereka beranggapan bahwa para nabi mereka banyak berbuat maksiat. Begitu juga dengan Nasrani, walaupun mereka mensucikan al-Masih dari segala aib dan cela, tapi pensucian mereka itu tidak berdasarkan kemampuan analogi ilmiah bahwa al-Masih itu manusia yang diutus untuk mengajarkan manusia dan menyelamatkannya. Tetapi menurut mereka ia adalah Tuhan yang berfisik. Oleh karena itu, mereka juga tidak perlu membahasnya karena 'ismah adalah masalah manusia bukan masalah Tuhan.

Para nabi dan rasul adalah manusia-manusia pilihan yang diutus oleh Allah SWT untuk memperbaiki ummat manusia. Mereka adalah pendidik, pendakwah, pembimbing sekaligus pemberi contoh kebaikan. Sebagai seorang pedidik, maka sudah sepatutnya sifat ma's $\underline{u}$ m ini melekat pada diri mereka demi melancarkan misi dakwah yang diembankan oleh mereka. Posisinya sebagai seorang nabi atau rasul sangatlah dituntut untuk menjadi teladan dalam segala hal. Di sinilah letak salah satu dari kemurahan hati Allah SWT kepada para nabi dan rasul-Nya. Ia memerintahkan untuk

\footnotetext{
${ }^{17}$ Al-Sâaûnî, Membela Nabi, hlm. 39
} 
menyampaikan risalah-Nya, tetapi Ia juga membekali mereka dengan 'ísmah. Dari pernyataan di atas, dapat dirinci bahwa seorang nabi atau rasul haruslah ma'sûm, karena di antaranya: (a) agar menjadi teladan bagi ummat manusia; dan (b) agar apa yang diwahyukan tidak luput sedikitpun baik karena kelupaan atau ketidakjujuran.

Sebagian para ulama berpendapat, 'ísmah terjadi sebelum dan sesudah diangkat menjadi nabi. Hal ini dikarenakan perjalanan hidup seseorang (meskipun belum menjadi nabi) mempunyai pengaruh terhadap perkembangan dakwahnya pada masa sesudah diangkat menjadi nabi. Oleh karena itu, setiap nabi wajib berperikehidupan yang baik dan berjiwa bersih sehingga tidak ada sandungan psikologis dalam mengemban risalah dan dakwahnya. ${ }^{18}$ Dalil yang digunakan adalah surat $\underline{T}$ âhâ ayat 39 dan surat $\underline{S}$ âd ayat 47 .

Menurut al-Ŝâûnî, Allah SWT telah menjaga nabi-Nya sejak kanak-kanak, Allah SWT melindunginya dari segala perilaku jahiliyyah pada masa kecil dan pada masa remaja hingga saat diangkat menjadi nabi. Dengan demikian sempurna pula kema'sûman dengan diberi tugas mengemban risalah. ${ }^{19}$ Ada juga yang berpendapat bahwa kema'sûman terjadi setelah kenabian, baik dari dosa besar maupun kecil, sebab manusia tidak diperintahkan mengikuti mereka sebelum diangkat menjadi nabi. Sebelum itu, mereka layakya manusia biasa, akan tetapi mereka tidak terjerumus dalam dosa.

Konsep 'ísmah menurut Taqiyyuddin al-Nabhani tidak berbeda dengan ulama lainnya, yaitu berupa pemeliharaan Allah SWT terhadap nabi-nabi-Nya dari dosa-dosa. Hanya saja, kema'sûman nabi dan rasul semata-mata terjadi setelah diangkatnya mereka sebagai nabi dan rasul bersamaan dengan wahyu yang disampaikan kepadanya. Adapun sebelum masa kenabian dan kerasulan — secara akal-boleh saja mereka melakukan hal-hal yang dibolehkan atas seluruh manusia, karena kema'ŝuman itu hanya untuk kenabian dan kerasulan. ${ }^{20}$

Mengenai dosa besar atau kecilkah yang ma's terhadap perkara yang secara pasti diperintahkan untuk dikerjakan dan diperintahkan untuk ditinggalkan - artinya mencakup seluruh perkara fardhu dan haram-mereka semuanya ma'sûm. Ma'ŝum dari meninggalkan perkara fardhu dan ma'ŝum dari perkara haram, apakah dosa itu kecil atau besar. Selain dari hal-hal tersebut, seperti yang makruh, mandûb dan khilâfatul aula, ${ }^{21}$ mereka tidak ma'ŝum, karena itu tidak bertentangan dengan kenabian dan kerasulan dan itu tidak tergolong maksiat.

Ibnu Taimiyyah juga ikut menyumbangkan pikirannya tentang konsep kema'sûman. Menurutnya, para nabi itu ma'ŝum hanya berkenaan dengan tugasnya menyampaikan wahyu (tablîgh) dari Allah SWT saja. Di luar tugas itu, para nabi sebagai manusia biasa, dapat melakukan kesalahan. Misalnya, pelanggaran Nabi Daud

\footnotetext{
${ }^{18}$ Al-Sâubûnî, Membela Nabi, h. 43-44

19 Al-Sâubûnî, Membela Nabi, h. 42

${ }^{20}$ Taqiyyuddin an-Nabhani, al-Syakhsiyyah al-Islamiyyah, juz.1 (Beirut: Dârul Ummah), h. 184

${ }^{21}$ Khilâfatul aula: melakukan sesuatu hal yang baik, akan tetapi ada hal lain yang lebih baik dan tepat untuk dilakukan (menyalahi yang lebih utama)
} 
AS, kelalaian Nabi Yunus AS, dan juga kelengahan Nabi Muhammad SAW, yang semuanya termaktub dalam al-Qur'an. Hanya saja, bila berbuat kekeliruan atau kesalahan, para nabi segera menyadarinya dan melakukan taubat nasuha (taubat yang tulus ikhlas). Justru taubat itulah yang mempertinggi kenabian dan kemanusiaan para nabi tersebut. Selain itu, bila berbuat salah atau keliru, para nabi tersebut segera mendapat peringatan atau teguran dari Allah SWT. ${ }^{22}$

Mengenai siapakah yang dianggap ma'sûm, sebagian besar ulama Sunni meyakini bahwa 'ísmah hanya dikhususkan bagi para nabi dan rasul. Tidak terdapat pada seorang pun selain mereka, sebab setiap manusia biasa selalu menjadi sasaran berbuat khilaf dan dosa.Berbeda dengan apa yang terdapat dalam kelompok Syi'ah, 'ismah tidak hanya berlaku untuk para nabi dan rasul tetapi juga bagi para imam dan wâsî mereka. Adapun dalil yang dijadikan hujjahnya adalah suratal-Ahzâb ayat 33.Al-'Allâmah Taba'tabai dalam menafsirkan ayat tersebut mengatakan bahwa "sesungguhnya Allah senantiasa memberikan kamu anugrah 'ismah, dengan menyingkirkan keyakinan yang bathil dan dampak perbuatan yang buruk dari kamu, wahai ahlul bait. Dan Allah menghendaki sesuatu yang dapat menghilangkan pengaruh yang jelek, itulah "ísmah." ${ }^{3}$ Pendapat ini berbeda jauh dengan pendapat kaum muslimin umumnya yang meyakini bahwa manusia selain nabi pasti pernah melakukan khilaf dan dosa.

\section{Penafsiran Terhadap Ayat-ayat 'Itâb}

Surat'Abasa [80] ayat1-12

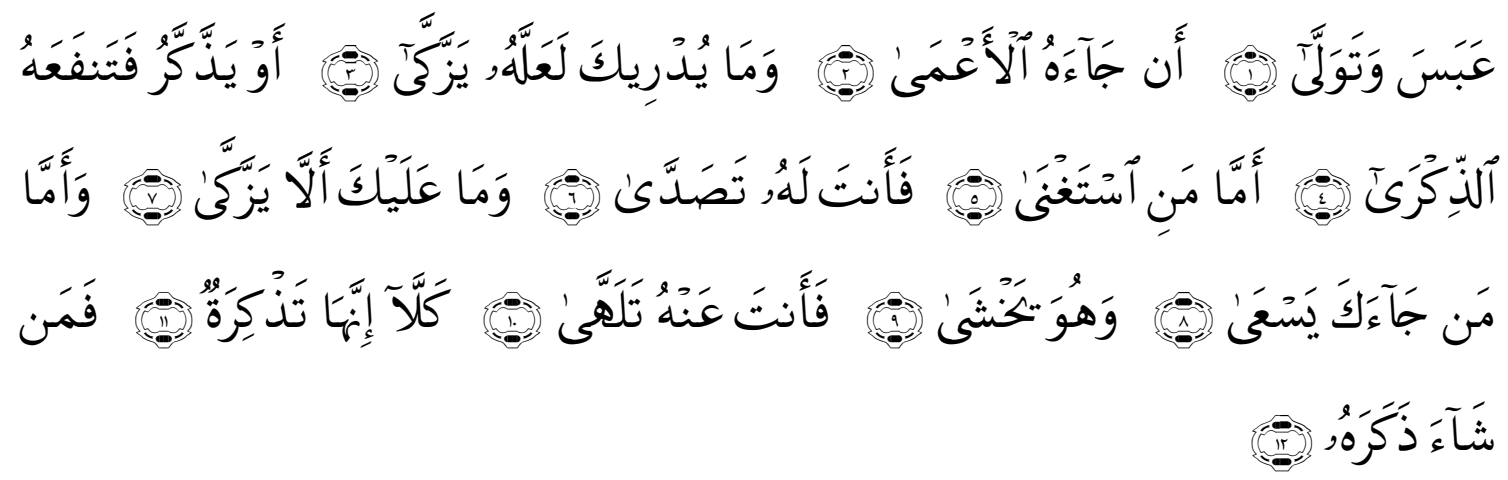

Artinya: Dia (Muhammad) bermuka masam dan berpaling, 2. Karena telah datang seorang buta kepadanya. 3. Tahukah kamu barangkali ia ingin membersihkan dirinya (dari dosa), 4. Atau Dia (ingin) mendapatkan pengajaran, lalu pengajaran itu memberi manfaat kepadanya? 5. Adapun orang yang merasa dirinya serba cukup, 6. Maka kamu melayaninya. 7. Padahal tidak ada (celaan) atasmu kalau Dia tidak membersihkan diri (beriman). 8. Dan Adapun orang yang datang kepadamu dengan bersegera (untuk mendapatkan pengajaran), 9. Sedang ia takut kepada (Allah), 10. Maka kamu mengabaikannya. 11. Sekali-kali jangan (demikian)! Sesungguhnya ajaran-

${ }^{22}$ Suplemen Ensiklopedi Islam, vol. II (Jakarta: PT IKhtiay Baru van Hoeve, 1996), h.135

23 Al-'Allâmah al-Sayyid Muhammad uusein al-Thabathabăi, Al-Mîzân fî̀ Tafsîr al-Qur'ân, jil. 16 (Qum: Jamâ'atu al-Mudarrisîn fî al-Hurah al-‘Ilmiyyah, tt), h 331 
ajaran Tuhan itu adalah suatu peringatan, 12. Maka Barangsiapa yang menghendaki, tentulah ia memperhatikannya, (QS. 'Abasa [80] : 1-2)

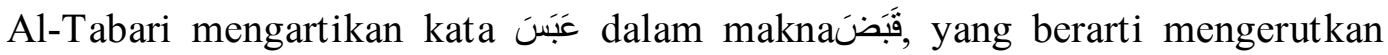
wajahnya. Sebagian qurrâ’ membaca kalimat أَنْ جَاءَهُ الْاعَمَىى pada ayat pertama surat

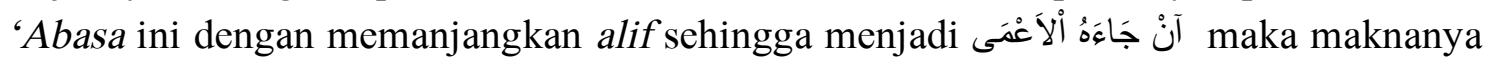

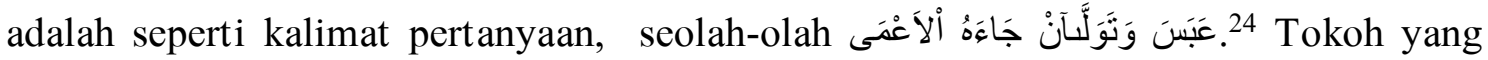
yang ditegur karena bermuka masam dalam surat ini adalah Nabi Muhammad SAW. Sedangkan ألَعََْ adalah Abdullah Ibnu Ummi Maktum, salah seorang sahabat Nabi SAW yang buta.

Ayat ini merupakan salah satu ayat 'itâb (teguran) yang dilontarkan oleh Allah SWT kepada Nabi-Nya Muhammad SAW. Ketika itu Nabi SAW sedang duduk bersama para pemuka Quraisy, di antaranya adalah 'Uthbah ibn Rabî'ah, al-Wâlid ibn Mughîrah, Abû Jahal ibn Hisyâm, dan al-'Abbâs ibn Abdul Mutâlib. Tujuan Nabi SAW duduk bersama mereka adalah untuk mendakwahkan Islam kepada mereka. Mereka adalah tokoh penting dalam masyarakat Arab saat itu. Keislaman mereka tentunya membawa pengaruh besar bagi perkembangan Islam selanjutnya. Itulah yang menjadi harapan Nabi SAW saat itu. Ketika Nabi SAW sedang berbincang-bincang dengan mereka, tiba-tiba salah seorang sahabat tunanetra datang menghampirinya, meminta untuk diajarkan apa yang telah Allah SWT wahyukan kepadanya. Ternyata, kedatangan sahabat tersebut, yakni Ibnu Ummi Makt ûm tidak tepat waktu, maka Nabi SAW pun cemberut (bermuka masam) kepadanya. Karena sikap Nabi SAW ini akhirnya teguran ini turun.

Sebagaimana diketahui bahwa Tafsir Al-Thabarî merupakan tafsîr bi al-ma'tsûr. Jadi ia sangat banyak mengutip riwayat-riwayat untuk menjelaskan ayat yang akan ditafsirkannya, termasuk surat ini. Di antaranya, yaitu:

Said ibn Yahya al-Umami menceritakan kepada kami, ia berkata: "ayahku menceritakan kepada kami dari Hisyâm ibn 'Urwah dari apa yang didapatnya dari 'Urwah, dari 'Âisyah, ia berkata: 'Abasa watawallâ diturunkan berkenaan dengan Ibnu Ummi Maktûm. Ia ('Âisyah) berkata lagi: “ia (Ibnu Ummi Maktûm) datang kepada Rasulullah SAW dan berkata kepadanya: ajarilah aku. 'Âisyah berkata: dan ketika Rasulullah bersama pembesar-pembesar musyrik. Ia ('Âisyah) berkata: lalu Nabi berpaling darinya dan menghadap kepada yang lainnya. Maka Ibnu Ummi Maktûm bertanya: Apakah aku mengatakan sesuatu yang salah? Nabi pun menjawab: tidak. Maka turunlah ayat 'abasa watawallầ $\hat{2}^{25}$ untuk menegur sikapnya tadi.

Lain halnya dengan Tafsîr al-Mîzân,Tabatabai menyebutkan bahwa ayat tersebut tidak ditujukan kepada Nabi SAW, tetapi kepada selainnya, karena al-'abûs (bermuka masam) itu bukanlah sifat dari seorang Nabi SAW. Tidak mungkin Nabi SAW melakukan hal seperti ini, sedangkan di ayat lain Allah SWT sudah mengklaim bahwa

\footnotetext{
${ }^{24}$ Abu Ja'far Muhammad ibn Jarîr al-Tabarî, TafsîrJami' al-Bayân 'an Tâwîl Âyi al-Qưrânjuz 30 (Beirut: Dârul Fikri, 1408 H / 1988 M), h. 50

${ }^{25}$ Al-Tabari, TafsîrJâmi' al-Bayân juz 30 h. 50
} 
ia adalah berbudi pekerti yang agung. ${ }^{26}$ Sebagian dari Syi'ah mengatakan bahwa yang ditegur dalam ayat tersebut adalah salah seorang laki-laki dari Bani Umayyah yang ketika itu juga sedang duduk bersama Nabi SAW. Laki-laki itulah yang bermuka masam melihat kedatangan Ibnu Ummi Maktum. ${ }^{27}$ Lebih lanjut ia mengatakan bahwa kata 'abasa dalam ayat ini ditulis dengan bentuk persona ketiga menunjukkan betapa kerasnya kecaman itu sampai-sampai Allah SWT berpaling darinya dan tidak pantas untuk berdialog dengannya secara face to face.

Sedangkan menurut Tafsir al-Mishbah, penyebutan kata 'abasa dalam bentuk persona ketiga, tidak secara langsung menunjuk Nabi SAW, mengisyaratkan betapa halus teguran ini, dan betapa Allah SWT pun-dalam mendidik Nabi-Nya-tidak menudingnya atau secara tegas menyalahkannya. ${ }^{28}$

Sikap Rasul SAW yang mendahulukan pemuka-pemuka Quraisy ini terdorong oleh harapan besar akan keislaman pemuka Quraisy dan rasa takutnya jangan sampai ia dinilai belum menjalankan tugasnya dengan baik, yaitu sebagai seorang muballîgh (penyampai). Pada saat itu Nabi SAW sama sekali tidak menghina dan mengabaikan Ibnu Ummi Maktûm karena kemiskinan dan kebutaannya. Ia juga tidak juga melayani orang-orang besar tadi karena kekayaan mereka kecuali hanya mengharap keislaman mereka. Apa yang dilakukan oleh Nabi SAW dalam peristiwa ini apabila dibandingkan dengan hari ini, maka tentu bukan masalah besar. Terlebih lagi apa yang dilakukan ini mempunyai alasan tertentu. Allah SWT menegurnya dalam surat ini tidak lain adalah karena ia adalah manusia teragung,sehingga sifat yang akan menimbulkan kesan negatif pun tidak dikehendaki untuk ia lakukan.

Berdasarkan penafsiran dari peristiwa di atas, dapat dipahami bahwa jika ayat 'itâb tersebut dikaitkan dengan konsep 'ísmah, maka sikap Nabi SAW yang ditegur oleh Allah SWT tersebut bukan bagian dari perbuatan dosa atau khilaf yang akan menafikan 'ísmah. Hal ini dikarenakan apa yang dilakukan oleh Nabi SAW tersebut merupakan perbuatan yang wajar dilakukan oleh manusia pada umumnya, terlebih ia sebagai seorang pemimpin dan tidak dianggap sebagai sebuah kesalahan yang mencoreng nama baik. Sebagai gambarannya adalah, wajar jika seorang pemimpin merasa sedikit cemberut jika ada seseorang yang ingin bertemu dengannya di saat ia sedang melakukan tugas lain yang lebih penting menurutnya dan tanpa perjanjian sebelumnya. Sikap'abûs Nabi SAW juga disebabkan harapan yang besar akan keislaman pembesar Quraisy dan ia ingin mendahulukan mereka baru kemudian melayani Ibnu Ummi Maktûm yang sudah masuk Islam. Apa yang dilakukan Nabi SAW dalam ayat ini sangat manusiawi dan bukan sebuah perbuatan dosa yang harus diberi sanksi. Namun karena besarnya kasih sayang Allah SWT kepada Nabi SAW maka Ia tidak ingin kekasih-Nya tersebut berbuat yang demikian karena ada sikap lain yang lebih utama untuk dilakukan walaupun pada hakikatnya ia tidak menyakiti Ibnu

${ }^{26}$ Al-Thabathabaii, Al-Mîzân, jilid 19, h. 203

${ }^{27}$ Al-Thabathabại, Al-Mîzân, jilid 19, h. 199

28 M. Quraish Shihab, Tafsir Al-Mishbah: Pesan, Kesan Dan Keserasian Al-Qur'an vol. 15 (Jakarta: Lentera Hati, 2002), h. 60 
Ummi Maktum dan ia pun tidak bisa melihat raut wajah Nabi SAW yang cemberut dengan kedatangannya karena ia adalah seorang tunanetra.

\section{Surat $A l-T a h r i ̂ m[66]$ ayat 1-5}

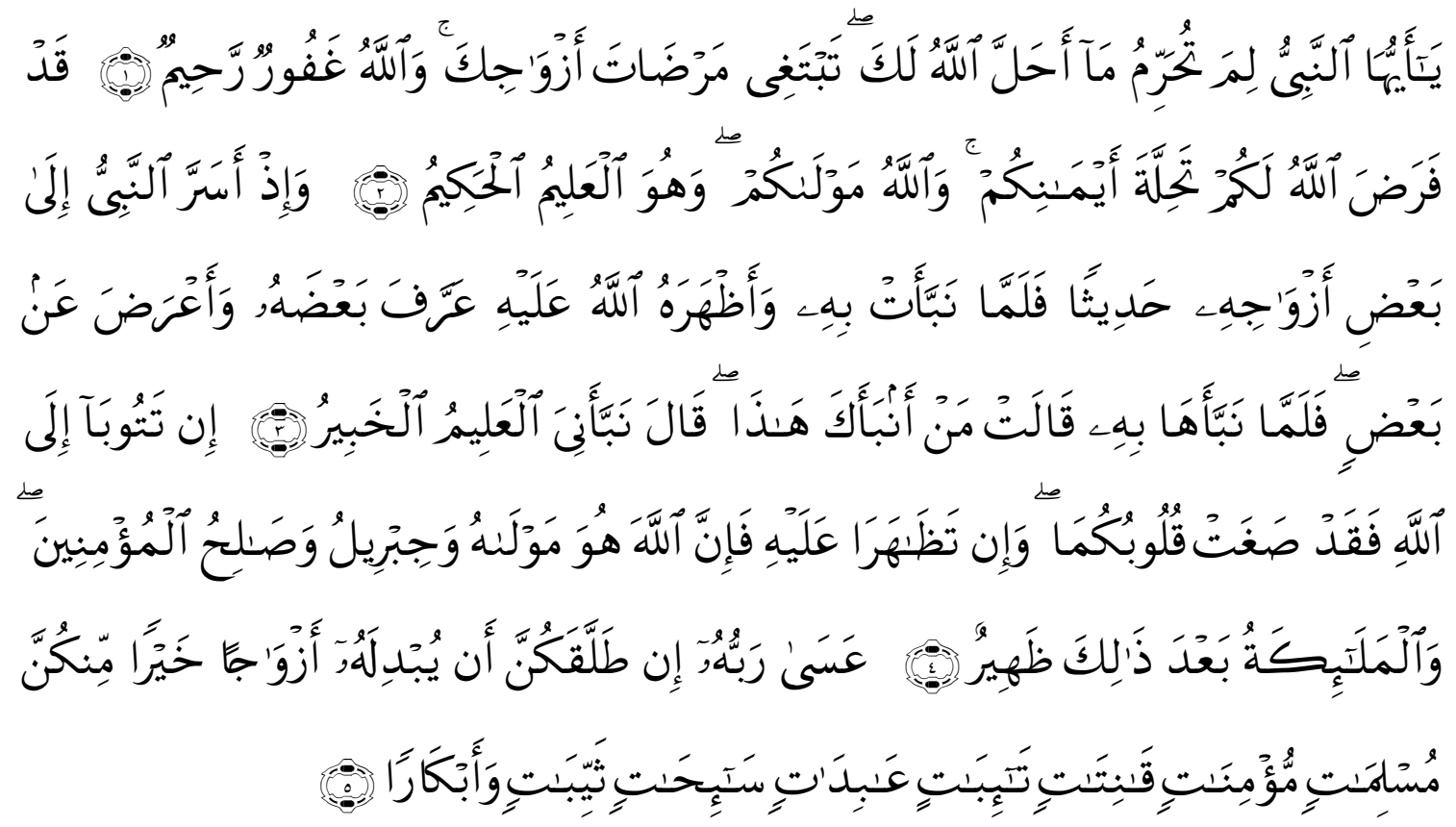

Artinya: "Hai Nabi, mengapa kamu mengharamkan apa yang Allah halalkan bagimu; kamu mencari kesenangan hati isteri-isterimu? dan Allah Maha Pengampun lagi Maha Penyayang 2. Sesungguhnya Allah telah mewajibkan kepadamu sekalian membebaskan diri dari sumpahmu dan Allah adalah Pelindungmu dan Dia Maha mengetahui lagi Maha Bijaksana. 3. Dan ingatlah ketika Nabi membicarakan secara rahasia kepada salah seorang isterinya (Hafsah) suatu peristiwa. Maka tatkala (Hafsah) menceritakan Peristiwa itu (kepada 'Âisyah) dan Allah memberitahukan hal itu (pembicaraan Hafsah dan 'Âisyah) kepada Muhammad lalu Muhammad memberitahukan sebagian (yang diberitakan Allah kepadanya) dan Menyembunyikan sebagian yang lain (kepada Hafsah). Maka tatkala (Muhammad) memberitahukan pembicaraan (antara Hafsah dan 'Âisyah) lalu (Hafsah) bertanya: "Siapakah yang telah memberitahukan hal ini kepadamu?" Nabi menjawab: "Telah diberitahukan kepadaku oleh Allah yang Maha mengetahui lagi Maha Mengenal." 4. Jika kamu berdua bertaubat kepada Allah, Maka Sesungguhnya hati kamu berdua telah condong (untuk menerima kebaikan); dan jika kamu berdua bantumembantu menyusahkan Nabi, Maka Sesungguhnya Allah adalah Pelindungnya dan (begitu pula) Jibril dan orang-orang mukmin yang baik; dan selain dari itu malaikat-malaikat adalah penolongnya pula. 5. Jika Nabi menceraikan kamu, boleh Jadi Tuhannya akan memberi ganti kepadanya dengan isteri yang lebih baik daripada kamu, yang patuh, yang beriman, yang taat, yang bertaubat, yang mengerjakan ibadat, yang berpuasa, yang janda dan yang perawan. (sebaiknya sebut rujukannya)". (QS. At-Tahrim [66] : 1-5) 
Al-Tabarî menyebutkan bahwa ayat ini diturunkan kepada Nabi Muhammad SAW berkaitan dengan masalah pribadinya dalam berumah tangga. Al-Tabarî di sini menjelaskan bahwa Rasulullah SAW mengharamkan sesuatu hal yang sudah dihalalkan oleh Allah SWT, yaitu salah satu istrinya yaitu Mâriyah al-Qibtiyyah. Pengharaman ini ia lakukan atas permintaan istrinya yang lain yaitu Hafsah dikarenakan kecemburuannya. Dikatakan bahwa kecemburuan itu muncul karena Nabi pernah menggilir Mariyah pada waktu giliran Hafsah dan di kamar Hafsah. Inilah yang memancingnya dan akhirnya meminta Nabi SAW untuk menjauhinya. ${ }^{29}$ Ada juga yang menyebutkan bahwa yang diharamkan oleh Nabi SAW adalah madu yang ia minum di rumah Zainab binti Jahsyi dan membuat dua istrinya yang lain ('Âisyah dan Hafsah) cemburu. Kemudian mereka berdua berencana jika Nabi SAW datang ke rumah mereka maka mereka akan mengatakan bahwa mereka mencium bau tidak sedap darinya sampai ia mengharamkannya.

Saat Rasulullah SAW memenuhi permintaan tersebut, ia meminta kepada Hafsah untuk tidak menceritakan kejadian tersebut kepada siapa pun. Permintaan Hafsah terhadap Nabi SAW yang akhirnya dipenuhinya ini ada yang menganggapnya sebagai sumpah. Dengan demikian ia harus membayar kifarat sumpah agar terlepas dari sumpah tersebut.

Salah satu riwayat yang disebutkan oleh al-Tabari adalah: Ibnu Hamid menceritakan kepada kami, ia berkata: Jarîr menceritakan kepada kami dari 'Amir tentang ayat ini berkenaan dengan istri yang didatanginya, maka muncullah Hafsah. Nabi berkata: "dia haram bagiku, maka sembunyikanlah ini, dan jangan ceritakan kepada siapa pun. Tetapi Hafsah menceritakannya. ${ }^{30}$

Sumpah yang diucapkan Nabi SAW ini harus ditunaikan kafaratnya karena apa yang dilakukannya adalah sesuatu yang sudah dihalalkan oleh Allah. Adapun kafaratnya adalah seperti kafarat sumpah pada umumnya, yaitu memberi makan atau pakaian kepada 10 orang miskin atau memerdekakan budak, dan ini tidak jatuh kepada thalak. $^{31}$

Terhadap sikap Nabi SAW ini, di akhir ayat Allah SWT berfirman bahwa Ia adalah Ghafûr Rahîm, dan Ia telah mengampuni Nabi SAW atas sikapnya itu. Setelah menceritakan sikap Nabi SAW di atas, ayat-ayat selanjutnya menjelaskan tentang sikap Hafsah yang membocorkan rahasianya dengan Nabi SAW kepada 'Âisyah. Dalam tulisan ini ayat-ayat tersebut tidak dibahas secara detail karena inti yang ingin didapat adalah pada ayat yang menjadi teguran Nabi SAW.

Dalam Tafsir al-Misbah disebutkan bahwa pertanyaan di atas تُحِرِمُ tentu saja bukan bertujuan bertanya, tetapi ia sebagai teguran sekaligus bermakna: "tidak ada alasan bagimu untuk melakukan hal tersebut, dan karena itu jangan mengulanginya dan tidak perlu juga engkau memenuhi ucapanmu itu. Bukan demikian itu cara

\footnotetext{
${ }^{29}$ Lihat selanjutnya : Tafsir al-Tabari, TafsîrJâmi' al-Bayân juz 28, h. 155

${ }^{30}$ Lihat selanjutnya: Tafsir al-Tabari, TafsîrJâmi' al-Bayân juz 28, h. 156-157

${ }^{31}$ Lihat selanjutnya: Tafsir al-Tabari, TafsîrJâmi' al-Bayân juz 28, h. 157
} 
menyenangkan istri dan mengorbankan pasanganmu yang lain." 32 Hal ini bermakna bahwa sangat lumrah juga jika seorang suami membahagiakan istrinya dengan usaha menjauhkan sesuatu yang tidak disukai oleh istrinya. Seperti suami yang berhenti mengkonsumsi pete yang tidak disukai oleh istrinya. Bisa jadi pengharaman tersebut hanya ditujukan untuk dirinya sendiri, tidak untuk kaum muslimin secara umum, namun Allah SWT tetap tidak berkenan karena kasih sayang Allah SWT lebih besar kepada Nabi-Nya. Sikap Nabi SAW ini juga bukan bagian dari sebuah kesalahan karena ia tidak bermaksud menghilangkan ketentuan hukum asal mubahnya mengkonsumsi madu, namun ia hanya ingin membahagiakan istrinya. Hal ini juga tidak menafikan konsep 'ismah padanya.

\section{Surat $A l-A \underline{h} z a ̂ b[33]$ Ayat 37}
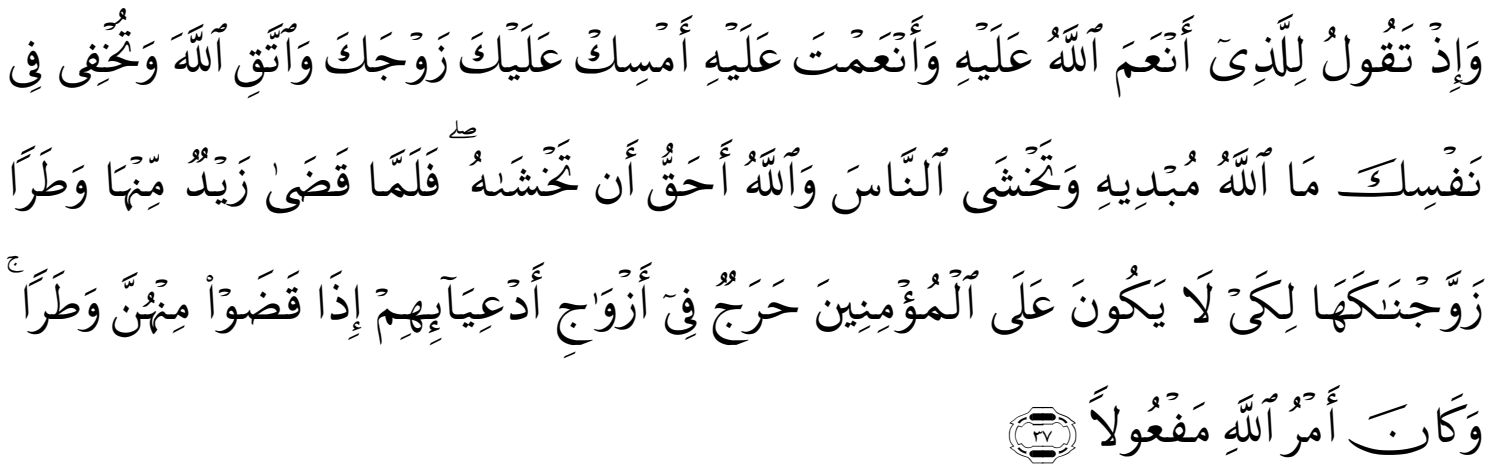

Artinya: "Dan (ingatlah), ketika kamu berkata kepada orang yang Allah telah melimpahkan nikmat kepadanya dan kamu (juga) telah memberi nikmat kepadanya: "Tahanlah terus isterimu dan bertakwalah kepada Allah", sedang kamu Menyembunyikan di dalam hatimu apa yang Allah akan menyatakannya, dan kamu takut kepada manusia, sedang Allah-lah yang lebih berhak untuk kamu takuti. Maka tatkala Zaid telah mengakhiri keperluan terhadap Istrinya (menceraikannya), Kami kawinkan kamu dengan dia supaya tidak ada keberatan bagi orang mukmin untuk (mengawini) isteriisteri anak-anak angkat mereka, apabila anak-anak angkat itu telah menyelesaikan keperluannya daripada isterinya. dan adalah ketetapan Allah itu pasti terjadi.(sebaiknya sebut rujukannya)". (QS. Al-Ahzâb [33] : 3)

Ayat ini juga menjelaskan tentang masalah pribadi Rasulullah SAW yang akhirnya menjadi sebab lahirnya sebuah ketentuan hukum fiqh baru, yaitu hukum bolehnya menikahi mantan istri anak angkat.

وَ وَإِْ نَقُوْلُ dalam ayat tersebut yang menjadi lawan bicaranya adalah Nabi

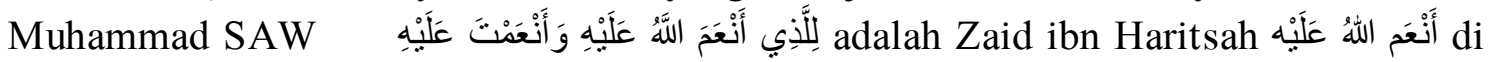

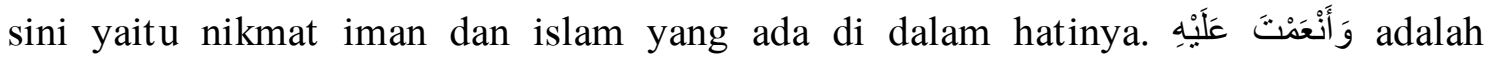
nikmatnya menjadi anak angkatnya Nabi SAW. Allah SWT menegur Nabi SAW dalam ayat ini karena ia menyembunyikan ketetapan Allah SWT yang telah ditetapkan

${ }^{32}$ M. Quraish Shihab, Tafsir Al-Mishbah, vol 14, h. 317 
baginya dari anak angkatnya, Zaid ibn Haritsah. Ketetapan tersebut adalah bahwa Nabi SAW akan menjadi suami dari istri anak angkatnya itu, yaitu Zainab binti Jahsyi.

Salah satu pendapat yang dinukil oleh al-Tabarî adalah: Khalad ibn Aslam menceritakan kepada kami, ia berkata: Sufyân ibn 'Uyainah menceritakan kepada kami

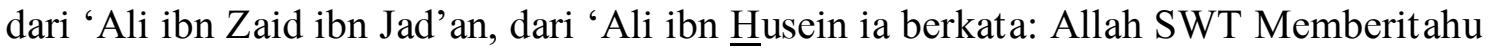
Nabi-Nya SAW bahwa Zainab akan menjadi salah satu istrinya. Maka ketika Zaid datang kepadanya untuk mengadu perihal rumah tangganya dengan Zainab, Nabi berkata kepadanya: bertakwalah kepada Allah dan tahanlah istrimu, maka Allah berfirman: dan kamu menyembunyikan apa yang ada di hatimu.

Masalah yang diangkat dalam ayat ini menyangkut rahasia keluarga Nabi SAW, akan tetapi Allah SWT tetap menuangkannya dalam kitab suci-Nya. Bahkan, 'Âisyah menyebutkan bahwa seandainya Rasulullah SAW menyembunyikan sesuatu dari apa yang diwahyukan oleh Allah SWT maka ia akan menyembunyikan ayat ini. Penulis melihat bahwa hal ini tentu tidak terlepas dari sifat maksum yang ada padanya sampai ia berlaku siddî $q$ dalam hal tablîgh al-risâlah walaupun itu masalah pribadinya.

Pernikahan Zaid dengan Zainab terjadi atas perintah Rasulullah SAW. Pada awalnya Zainab menolak karena ia berasal dari keluarga yang terhormat dan cantik sedangkan Zaid hanyalah anak angkat yang dahulunya adalah seorang budak. Namun atas perintah Rasul SAW dan merupakan wahyu Allah SWT maka Zainab pun menerimanya. ${ }^{33}$ Ada riwayat lain yang menyatakan bahwa ayat sebelumnya turun berkenaan dengan Ummu Kaltsum binti 'Uqbah ibn Abî Mu'ith-yang merupakan wanita pertama yang berhijrah setelah Perjanjian Hudaibiyyah. Wanita itu datang kepada Nabi SAW menyerahkan diri (mengharap dinikahi olehnya). Rasul SAW menerima dan mengawinkannya dengan Zaid ibn Haritsah (boleh jadi setelah penceraiannya dengan Zainab). Wanita tersebut demikian juga saudaranya marah atas perkawinan itu. Saudaranya berkata: "Kami mengharapkan Rasul, tetapi ternyata ia kawinkan dengan bekas budaknya." 34

Bentuk kata kerja mudhâri' (taqûlu) bertujuan menghadirkan ucapan ke dalam benak mitra bicara dan pendengarnya sekaligus mengisyaratkan bahwa nasihat Nabi SAW itu berulang kali. ${ }^{35}$ Dalam ayat tersebut Zaid digambarkan sebagai seorang yang mendapatkan nikmat dari Nabi SAW dan ini menunjukkan bahwa betapa dekat dan akrabnya ia dengan Rasulullah SAW. Bahkan sebelum ayat ini turun ia pernah dipanggil dengan nama Zaid ibn Muhammad, walaupun statusnya sebagai anak angkat. Tentu saja Rasulullah sebagai ayahnya sangat menginginkan kebahagiaan dan kemaslahatan baginya, termasuk dalam hal mempertahankan rumah tangganya.

Sebab turunnya ayat ini telah menimbulkan isu dan tanggapan negatif. Rasulullah SAW telah menyadari akan terjadinya hal ini, namun Allah SAW bermaksud membatalkan sebuah ketentuan hukum dan menggantinya dengan

\footnotetext{
${ }^{33}$ Ini adalah sebab turunnya ayat sebelumnya (ayat 36)

${ }^{34}$ M. Quraish Shihab, Tafsir Al-Mishbah vol. 11 h. 276

${ }^{35}$ M. Quraish Shihab, Tafsir Al-Mishbah vol. 11, h. 279
} 
ketentuan lain yang lebih besar hikmahnya, yaitu dampak adopsi secara amaliah dan langsung dilakukan oleh Rasulullah SAW sendiri, sehingga menjadi jelas bagi semua pihak. Penulis melihat bahwa sikap Nabi SAW menyembunyikan perintah Allah SWT dari Zaid bukan karena ia tidak bersifat tabligh, tetapi lebih didasari oleh faktor kasih sayangnya dan masih menunggu waktu yang tepat. Terlebih lagi Zaid datang dan mengadu kepada ayah angkatnya tersebut, maka rasa kebapakannya pun muncul. Ini bukanlah kesalahan, tetapi Allah SWT menginginkan Nabi-Nya mengambil sikap lain yang lebih utama yaitu dengan berterus terang kepada Zaid.

\section{Surat Al-Anfâl [8] ayat 67}

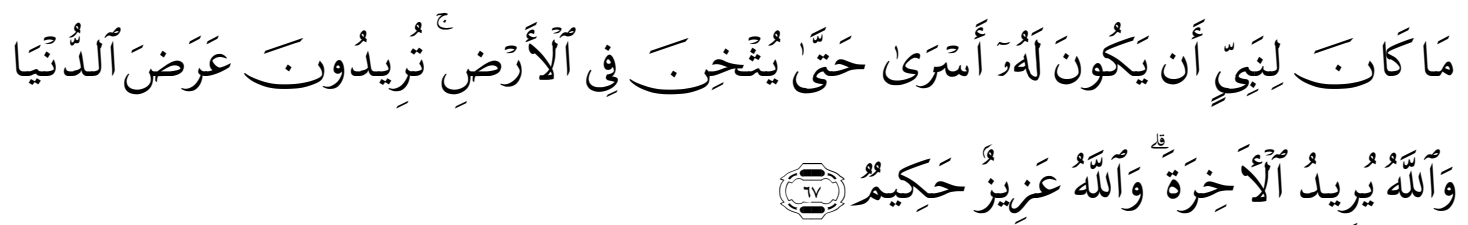

Artinya: "Tidak patut, bagi seorang nabi mempunyai tawanan sebelum ia dapat melumpuhkan musuhnya di muka bumi. kamu menghendaki harta benda duniawiyah sedangkan Allah menghendaki (pahala) akhirat (untukmu). dan Allah Maha Perkasa lagi Maha Bijaksana. (sebaiknya sebut rujukannya)". (QS. Al-Anfâl [8] : 67)

Ayat ini turun sesudah terjadinya perang Badar. Dalam perang tersebut kaum muslimin memperoleh kemenangan yang begitu menggembirakan. Di samping menewaskan musuh dan memperoleh rampasan perang, kaum muslimin juga berhasil menawan tujuh puluh dari kaum musyrikin. Menghadapi para tawanan ini, Nabi Muhammad SAW meminta pendapat para sahabat menyangkut tindakan yang akan diambil terhadap mereka. Dalam hal ini al-Tabarî meyebutkan beberapa riwayat yang mneguraikan tentang musyawarah Nabi SAW dengan para sahabatnya. ${ }^{36}$ Disebutkan bahwa Abû Bakar RA ketika itu mengusulkan bahwa mereka dibebaskan saja dengan membayar tebusan, karena mereka juga adalah orang terdekat dan kerabat Nabi SAW sendiri. Jika tidak mampu maka harus mengajar kaum muslimin untuk membaca dan menulis. Lain halnya dengan yang diusulkan oleh 'Umar ibn Khattâb RA. Ia menyarankan agar mereka dibunuh karena mereka adalah kaum kafir Quraiys. Setelah bermusyawarah dengan para shahabat maka Nabi SAW memutuskan untuk menerima ide Abû Bakar RA. Namun tindakan ini ditegur oleh Allah SWT

Dalam al-Mishbah disebutkan bahwa ayat ini tidak menegur Nabi Muhammad, akan tetapi Abû Bakar RA selaku pengusul. Teguran ini bukanlah karena ia berbuat kesalahan yang besar, hanya saja kurang tepat apabila diberlakukan pada saat itu. Karena kondisi umat Islam saat itu masih dalam jumlah yang sedikit. Mengambil pendapat Abû Bakar RA adalah suatu hal yang kurang tepat karena bisa jadi setelah mereka bebas maka mereka akan kembali menyerang Islam dan Nabi SAW. Maka jalan

\footnotetext{
${ }^{36}$ Tafsir al-Tabarî, Tafsî̀Jâmi’ al-Bayân juz 10, h. 42-44
} 
yang tepat untuk diambil adalah dengan membunuh mereka seperti usulan 'Umar ibn Khattâb RA. Dengan memilih usulan ini, maka akan mempercepat laju perjuangan dan penguasaan Islam terhadap negara-negara musyrik.

Memang bukan sebuah pilihan yang salah ketika Nabi SAW menerima usulan Abû Bakar RA untuk membebaskan tawanan dengan kewajiban membayar tebusan, akan tetapi melihat kondisi umat Islam yang saat itu masih lemah maka Allah SWT menegurnya karena ada pilihan lain yang lebih utama. Hal ini juga tidak merusak konsep 'ismah karena belum ada ketentuan dari Allah SWT tentangnya sedangkan ummat Islam saat itu memerlukan jawaban yang cepat.

\section{Surat Al-Taubah [9] Ayat 43}

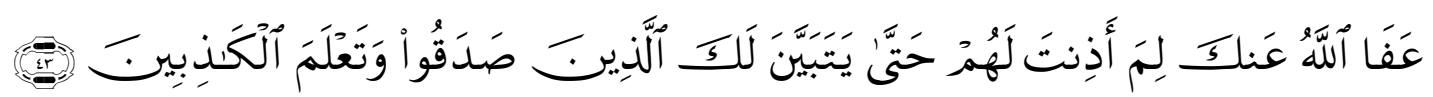

Artinya: "Semoga Allah memaafkanmu. Mengapa kamu memberi izin kepada mereka (untuk tidak pergi berperang), sebelum jelas bagimu orang-orang yang benar (dalam keuzurannya) dan sebelum kamu ketahui orang-orang yang berdusta? (sebaiknya sebut rujukannya)". (QS. Al-Taubah [9] : 43)

Al-Tabarî menyebutkan bahwa ayat ini berkenaan dengan teguran Allah kepada Nabi Muhammad SAW, karena telah mengizinkan sekolompok orang yang enggan berperang (al-mutakhallifunn). ${ }^{37}$ Diceritakan bahwa pada saat itu Nabi SAW dan para sahabat sedang dalam masa mempersiapkan diri untuk berperang dalam perang Uhud (Khandaq). Sebagian para sahabat begitu ant usias menyembut seruan jihad itu. Namun ada juga sebagian orang yang merasa enggan untuk ikut berperang. Maka mereka pun mendatangi Rasulullah agar diizinkan untuk tidak berperang. Bahkan seraya bersumpah mereka mengatakan bahwa mereka akan berangkat berperang jika mereka sanggup. Permohonan izin yang mereka sampaikan ini ternyata langsung diiyakan oleh Rasulullah SAW, tanpa terlebih dahulu memastikan siapa saja di antara mereka yang benar-benar tidak bisa ikut berperang ( 'udzur) dan siapa saja yang memang benar-benar enggan (malas).

Di antara riwayat yang dituliskan oleh al-Tabari adalah bahwa al-Harts menceritakan kepadaku: ia berkata: ada dua hal yang dilakukan oleh Rasulullah SAW, sebelum ada perintah apa-apa, yaitu mengizinkan orang-orang munafiq (untuk tidak ikut berperang) dan mengambil para tawanan perang. Maka Allah pun menurunkan ayat ini (Semoga Allah memaafkanmu. Mengapa kamu memberi izin kepada mereka (untuk tidak pergi berperang).

Lain halnya dengan pendapat Tabatabai, ia mengatakan bahwa ayat tersebut memang ditujukan kepada Nabi SAW, akan tetapi pada hakikatnya yang dikecam adalah orang-orang yang meminta izin dan bersumpah tersebut. ${ }^{38}$

Kata 'afa terambil dari akar kata yang maknanya berkisar pada dua hal, yaitu meninggalkan sesuatu dan memintanya. Dari sini lahir kata 'afwun yang berarti

\footnotetext{
${ }^{37}$ Lebih lanjut lihat: Tafsir al-Tabari, TafsîrJâmi' al-Bayân juz 10, h. 142

${ }^{38}$ Al-Tabatabại, Al-Mîzân, jilid 9, h. 285-286
} 
meninggalkan sanksi terhadap yang bersalah (memaafkan). Perlindungan Allah SWT dari keburukan dinamai 'âfiyah karena perlindungan mengandung makna ketertutupan. Dari sini kata 'afwun juga diartikan menutupi, bahkan dari rangkaian tiga huruf itu juga lahir makna terhapus, atau habis tiada berbekas, karena yang terhapus dan habis tidak berbekas pasti ditinggalkan. Selanjutnya, ia bisa bermakna berlebihan, karena yang berlebih seharusnya tidak ada dan ditinggalkan, yakni dengan memberi siapa yang memintanya. ${ }^{39}$ Redaksi ini biasa digunakan oleh orang Arab dalam arti semoga dimaafkan, yakni sebagai doa. Karena ini adalah firman Allah SWT, maka ia adalah kepastian.

Apabila ditelusuri lebih lanjut, maka ayat ini tidak menjadikan Rasul SAW berdosa, apalagi kelanjutan ayat-ayat berikutnya (46-47) memang menyatakan bahwa mereka (orang-orang munafik) tidak layak untuk ikut perang. Di samping alasan lain adalah karena Nabi SAW merupakan seorang yang bersifat lemah lembut sehingga wajar jika ia mengizinkan mereka untuk tidak ikut dalam berperang. Keputusan yang diambil Nabi SAW ini seperti Firman Allah SWT dalam surat al-Nûr ayat 62 yang memerintahkannya untuk memberi izin kepada yang memintanya.

Teguran ini hanya menyangkut waktu pemberian izin saja. Sebaiknya Rasul SAW mengizinkan mereka setelah terlebih dahulu melihat mana yang 'udzur dan mana yang malas, tidak langsung menerima permohonan tanpa membuktikan kebohongan mereka. Atas dasar inilah mayoritas para ulama menilai bahwa pada hakikatnya Rasul SAW tidak bersalah, hanya saja tidak melakukan yang terbaik (khilâf al-aulậ).

Dari beberapa ayat di atas dapat dilihat bahwa Rasulullah SAW sudah melakukan suatu tindakan yang baik dan tidak dianggap sebagai sebuah kesalahan dan dosa, akan tetapi kurang lebih utama menurut Allah SWT. Allah SWT menegurnya agar apa yang dilakukan atau yang diputuskan olehnya diganti dengan yang lain yang lebih tepat dan lebih utama. Apabila tindakan-tindakan di atas dilakukan oleh orangorang biasa maka hal itu tidak akan berdampak negatif serta tidak perlu ditegur karena hal itu adalah hal yang wajar bagi manusia biasa selain Nabi SAW. Hal ini seperti kaidah:

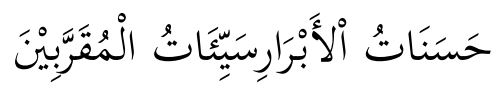

Artinya: Kebaikan yang dilakukan oleh pembakti kepada Allah dapat dinilai keburukan jika dilakukan oleh mereka yang didekatkan kepada-Nya.

Di samping itu, Allah SWT menegur Nabi Muhammad SAW karena rasa kasih sayang-Nya kepada Nabi-Nya dan tidak ingin kekasih-Nya terlalu memberatkan diri dan memaksakan diri dalam berdakwah sampai seperti memcelakakan dirinya sendiri. Jadi, teguran ini merupakan wuud kasih sayang Allah SWT kepada Nabi Muhammad SAW. Hal ini seperti firman-Nya dalam surat Fâtir /35: 8 yang melarangnya yang terlalu bersedih karena banyaknya yang tidak beriman dan mendustainya. Dengan demikian, ayat-ayat

${ }^{39}$ M. Quraish Shihab, Tafsir Al-Mishbah vol. 5, h. 606 
yang menegur Nabi SAW ini sama sekali tidak merusak konsep 'ismah al-anbiyâa, sehingga para nabi dan rasul tetap ma'sûmûn.

Adanya ayat-ayat teguran ini sama sekali tidak menyebabkan rendahnya derajat al-Qur'an dan para nabi. Hal ini justru membuktikan bahwa al-Qur'an benar-benar dari Allah SWT yang diwahyukan kepada Nabi Muhammad SAW dan ia maksum dalam menyampaikannya tanpa disembunyikan sedikit pun. Ayat-ayat inimembuktikan bahwa Nabi Muhammad SAW bersifat jujur. Ia menyampaikan semua ayat yang turun kepadanya walaupun menyangkut rahasia pribadinya.

\section{Penutup}

Berdasarkan uraiandi atas, maka dapat disimpulkan bahwa al-Tabari mengakui adanya ayat-ayat teguran bagi Nabi Muhammad SAW di dalam al-Qur'an, berbeda dengan alTabatabai yang tidak menganggap adanya teguran bagi Nabi SAW, tetapi bagi pihak lain. Teguran tersebut yang ada bukanlah karena suatu kesalahan atau dosa yang diperbuat oleh Nabi saw, melainkan karena wujud kasih sayang Allah SWT kepadanya agar tidak terlalu memberatkan diri atau memaksakan diri dalam berdakwah, karena bagaimana pun ia sudah melakukan semua perintah Allah SWT yaitu menyampaikan semua risalah-Nya. Dengan demikian, ayat-ayat yang menegur Nabi SAW ini sama sekali tidak merusak konsep 'ismah al-anbiyâa, sehingga para nabi dan rasul tetap ma'sum.(Ini bukan kesimpulan, melainkan keringkasan; seharusnya diungkap simpul bahasan bukan ringkasannya) 


\section{DAFTAR PUSTAKA}

'Abdul Al-Raûf Al-Manâwî, al-Ta'ârif, (Beirut: Dâr al-Fikr, 1410).

Al-'Allâmah al-Sayyid Muhammad Husein al-Thabathabại, Al-Mîzân fî Tafsîr alQur'ân, (Qum: Jamâ'atu al-Mudarrisîn fî al-Hurah al-'Ilmiyyah, tt).

Abu Ja'far Muhammad ibn Jarîr al-Tabarî, TafsîrJami' al-Bayân 'an Tăwîl Âyi alQưrân, (Beirut: Dârul Fikri, 1408 H / 1988 M).

Amîn Muhammad Salâm Al-Munâsiyah, Nąrah fî̀ Âyât al-'Itâb, dalam Majalah Jâmi 'ah Damsyîq li al-'Ulûm al-Iqtịsâdiyyah wa al-Qânûniyyah, edisi 23, 2007.

Atabik Ali dan Ahmad Zuhdi Mahdhar, Kamus al-'Asrî, (Yogjakarta: Multi Karya Grafika, 1998).

Ibnu Jauzi, al-Wafa; Kesempurnaan Pribadi Nabi Muhammad SAW, ed. 2.Penerjemah Mahfud Hidayat dan Abdul Muiz (Jakarta: Pustaka al-Kautsar, 2008).

Ja'far Subhani, Ishmah: keterpeliharaan Nabi Dari Dosa. Penerjemah Syamsuri Rifa'i (ttp. Penerbit Yayasan As-Sajjad, 1405 H / 1991 M).

M. Quraish Shihab, "Ibnu Jarîr al-Tabari; Guru Besar Para Ahli Tafsir," Ulumul Qur'an, (April-Juni 1989).

M. Quraish Shihab, Tafsir Al-Mishbah: Pesan, Kesan Dan Keserasian Al-Qur'an, (Jakarta: Lentera Hati, 2002).

Mani’ Abd Halîm Mahmụ̂̂, Metodologi Tafsir ; Kajian Komprehensif Metode Para Ahli Tafsîr. Penerjemah : Faisal Saleh dan Syahdianor (Jakarta : PT RajaGrafindo Persada, 2006).

Muhammad Husein al-Dzahabi, al-Tafsîr wa al-Mufassirûn, juz I, (Kairo: Maktabah Wahbah, t.t.).

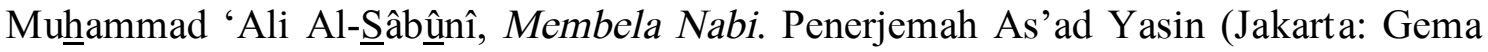
Insani Press, 1412 H / 1992 M).

Muhammad Amîn Al-Ị̣sân Al-Burtakî, Qawâ'id al-Fiqh, jil. 1, (Bibalsyâriz: Tab‘u alSadfi, 1986).

Muslim Nasution, dkk., "Ishmah," Syahrin Harahap dan Hasan Bakti Nasution, ed., Ensiklopedi Aqidah Islam, (Jakarta: Kencana, 2003).

Suplemen Ensiklopedi Islam, vol. II (Jakarta: PT Ichtiar Baru van Hoeve, 1996).

Șalâh'Abdu Al-Fattâh Al-Khâlidî, 'Itâb al-Rasûl fî̀ al-Qựân: Tahlîl wa Taujîh, (Damsyîq: Dâr al-Qalam, 2002).

Taqiyyuddin an-Nabhani, al-Syakhsiyyah al-Islamiyyah, juz.1 (Beirut: Dârul Ummah), h. 184 